\title{
The Perceived Resilience on Community Urbanization
}

\author{
${ }^{1}$ Pauline B. Malabanan \& ${ }^{2}$ Emilia S. Visco
}

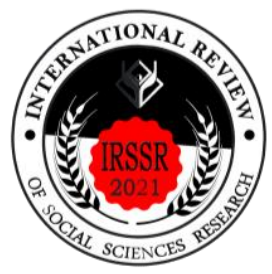

\begin{abstract}
Urbanization could provide benefits to community such as increase of income, access to services, and improved infrastructure due to the economic improvement and growth of investor. If not handled properly, risk from the shocks of this process must be mitigated by the community. With this, developing cities should manage its resources and be innovative so as to achieve community resiliency in the adverse effects of urbanization. To assess resiliency, modified sustainable livelihood framework with three variables; vulnerability context, community assets, and innovations was used. One area of interest is Cabuyao City, the youngest declared City in Laguna, as it is experiencing rapid urbanization. Changes in community budget, institutionalization, increased services, and influx of migrants were evident in the area. In addition, the offshoot of urbanization effects in the community assets of Barangay Sala which is considered Category 1 Urban Barangay and Barangay Casile, a Category 2 Urban Barangay has differences as they felt urbanization in different timeframe and the variation of the intensity of the impact brought by urbanization. With this, the two barangays have planned and implemented various innovation. The resiliency of the areas is determined in the linkages of these variables on how it managed its resources effectively and mitigate the negative effects using the policies, programs and projects designed by the community leaders.
\end{abstract}

Keywords:

community resilience, urbanization, sustainable livelihood framework, perceived resilience

Suggested Citation: Malabanan, P.B. \& Visco, E.S. (2021). The Perceived Resilience on Community Urbanization. International Review of Social Sciences Research, Volume 1, Issue 3, pp. 1- 24.

\footnotetext{
About the authors:

${ }^{1}$ Department of Social Development Services, College of Human Ecology, University of the Philippines, Los Banos ${ }^{2}$ Professor, Department of Social Development Services, College of Human Ecology, University of the Philippines, Los Banos
} 


\section{Introduction}

Urbanization has been defined in different ways from various studies and perspectives as the topic attracted many scholars around the globe. As defined by Chaolin, et.al (2015), urbanization, as a process, is based on industries present in an area with secondary and tertiary industries increasing rather than the primary industries. This means that working conditions and population is changing from agricultural to industrial and commercial. It also refers to the increase of population in urban areas as people shift from rural to urban (Sanyaolu and Sanyaolu, 2018). The change in settlement patterns brought transition in the society. The process of urbanization provided transformation in economic, social and cultural aspects of the society (Husian and Imitiyaz, 2018).

In the Philippines, the level of urbanization is measured through the number of population residing in urban areas. The urbanization rate recorded last 2015 was 51.2\% meaning that around 51.73 million people are residing in urban classified barangays (Philippine Statistic Authority, 2019). It is estimated that half of the country's population is residing in 7,437 urban barangays and the rest are in 34,599 rural barangays. As stated by Ling Ooi (2007), the country experienced rapid urbanization from the last four decades as rural people migrated to cities for the opportunities betterment of life. The process has positive implications such as better health services, more job opportunities and an increased overall income of the population. As tackled by Chaolin (2019), population is dense in urban areas which allow employers to access a large pool of candidates and vice versa in job matching. Furthermore, those living in urban setting has advantage in proximity and access to basic services.

However rapid urbanization, if not handled properly, may pose negative impacts in the area. It causes great uncertainties to community members due to rapid population growth and the difficulty to manage community assets. The process may present consequences and as a result, community members experience a high vulnerability context due to shocks and trends of this phenomenon (Ernston, et.al, 2010).

Cabuyao City is one suitable area of study. The city is located in the CALABARZON Area which has the largest population and second densely populated region in the Philippines (Mojares, 2013). Furthermore, Cabuyao City, classified as the Enterprise City of the 
Philippines, was among the third component cities that were listed as "entirely urban" in 2015 even Cabuyao has only in its 3rd year declared as cityhood.

These conditions imply that the City is quickly developing, and its situation is an interesting one as it has almost, if not completely, transitioned into an urban center. This paper will investigate two barangays, one is classified as Category 1 urban barangay and the

other is in Category 2 - comparing the effects of rapid urbanization to each barangay and examining the resilience through the use of Sustainable Livelihood Framework. Urban Barangays in the Philippines are categorized in to three categories (National Statistics Office, 2010).

1. Category 1 - has a population of more than 5,000 .

2. Category 2 - an area with at least one establishment employing 100 persons.

3. Category 3 - Five establishment present employing 10-99 persons and having five or more facilities in the two-kilometer radius from the barangay

The research assessed the perceived resilience of Barangay Casile and Barangay Sala of Cabuyao City on urbanization. The specific objectives are: to discuss the vulnerability context to urbanization of Cabuyao City, Laguna; to examine the effects of the trends and shocks of urbanization to the barangays in terms of (a) human capital, (b) social capital, (c) financial capital, (d) physical capital, and (e) natural capital; and to present the innovation of the public officials through policies, programs, and projects to alleviate the negative effects of urbanization.

The study could also enlighten researchers on how the sustainable Livelihood Framework (SLF) could be practiced in the concept of resilience and how resilience can be applied to study of urbanization. Furthermore, it only aims to assess resilience based on the indicators and components of SLF.

\section{Literature review}

\subsection{Effects of Urbanization in the Community}

As stated by Dociu and Dunarintu (2012) in their study entitled, "The SocioEconomic Impact of Urbanization", the process of urbanization brought various impacts on 
the social and economic status of a community. One of the social effects is a growth in new types of family structures compared to traditional forms due to the diverse options an individual has in urban areas. Furthermore, people opt to have a smaller number of families. It was also seen that there is an increase in participation of women in the labor market balancing professional and family responsibilities. Also, individuals form collective units in their community. In urban areas, it is convenient for the population to access jobs due to increase in work markets. Same can be seen in access to education. If not managed properly, urbanization brought negative impact on the environment. In addition, issues like poverty, psychological adaptation problems and lack of opportunities are present in urban areas.

Economic impacts are also present in the community in the process of urbanization. Cities have diverse commercial activities which create opportunities and jobs. This connects the population to business owners, services and infrastructure. People residing in urban areas also have access to increasing new technologies.

With the various effects of urbanization on communities, it is important that policy makers and governments strategically plan and urgently adopt to mitigate the negative impacts of the process. In order to achieve adaptation, planning shall be grounded to sustainable development taking into consideration the impact of environmental conditions on the lives of people (Dociu and Dunarintu, 2012).

In Southeast Asia, 47\% of the region's population lives in urban cities with an urban growth of $3.6 \%$ annually. With this, the region is rapidly urbanizing. The $47 \%$ of the population contributed around $80 \%$ of its economic growth. As a matter of fact, the growth domestic product (GDP) of Southeast Asia tripled from \$444 million to \$1.3 billion in 1990 to 2012. This economic resilience is due to demographic expansion, connection to domestic and international markets, improved business practices and competition in investment among cities as stated by Dahiya (2014).

Due to the growing economy in the urban areas, there is a shift of employment from primary to secondary and tertiary sector. However, there is a pressing concern on the employment of vulnerable and low wages sector. As stated by Dahiya (2014), around 32\% of the population are under the working poverty rate where family has an income below the poverty line and 81 million are living under the income threshold of $\$ 1.25$ a day. Urban 
poverty declines slower than rural poverty due to three reasons; (a) a higher income is needed to support living in urban areas, (b) policy makers in rural areas are focus in poverty alleviation programs, and (c) redistributive channels to benefit urban poor are not present in Asian Cities (Dahiya, 2014).

Furthermore, according to Dahiya (2014), 80 million in the Southeast Asia region are living in slum areas due to urban poverty and inequality. Even with the improvement of economic development, there is a pressing issue in poverty incidence, environmental degradation and consumption. In urban areas, a lack of infrastructure and services like safe water supply and sanitation contributes to water pollution which later on results in irreversible damage to the environment. Lack of resources for wastewater treatment affected the quality of groundwater. Lack of improvement in mass transit resulted in more people buying cars and motorcycles contributing to traffic congestion. Furthermore, transmission from these vehicles and industries contributes to air pollution. Therefore, the present infrastructure and services cannot keep up with the increasing population in urban areas.

\subsection{Urbanization in Region IVA: Cavite, Laguna, Batangas, Rizal and Quezon (CALABARZON)}

Region IVA or popularly known as CALABARZON is composed of 5 provinces namely CAvite, LAguna, BAtangas, Rizal, and QueZON. The region has a total population of 14.4 million which is 1.53 million higher than the National Capital Region. In addition, there is an increase in the number of cities in the region from 14 in 2010 to 19 last 2015. The increasing number of population and cities is a manifestation that the area is experiencing urbanization. In-migration, high birth rate, and increasing life expectancy are the major factors of the region's population growth rate which can mainly be seen in more industrialized areas of the region namely; Laguna, Cavite, and Rizal. These provinces are alongside Metro Manila and act as "catch basin" of NCR's population and industries. The percentage distribution of urban-rural population of the region also shows that urban population is increasing compared to rural population (NEDA Calabarzon, 2019).

Developments are also seen in the region. In terms of transportation, a 25.2 kilometer increase is seen in the CALABARZON's National Road. Same can be seen in the length of 
its bridges from 18,547 linear meters to 18,575.17 linear meters. There is also development on the existing expressway namely South Luzon Expressway (SLEX) Toll Road 4 which connects from Sto. Tomas, Batangas to Malayao, Lucena City and Cavite - Laguna Expressay (CALAEX) connecting CAVITEX and SLEX. Calamaba and Los Banos Railways are both operational. While Batangas and Quezon ports are both important water transportation facilities bridging the region to MIMAROPA and Western Visayas (NEDA Calabarzon, 2019).

Even with the developments happening in the region, there are also adverse effects brought by urbanization. As stated by Mojares (2013), poverty incidence in the region increased within 2003 to 2009. 18 out of 100 persons are reported poor in 2003 which increased to 21 in 2009. Rizal has the lowest poverty incidence and Quezon being the highest. This can be attributed to the agricultural setting of Quezon and the main employment of residents is farming. However due to the changing climate and the Philippines being prone to natural disasters, most farmers live below the poverty line. Furthermore, the unemployment rate of the region is $9.4 \%$ - 2nd highest in the country with Quezon being the highest as mainly are engaged in 'sari sari' store and agriculture.

CALABARZON is 2nd highest next to NCR in terms of number of informal settlers. People from rural areas migrate for high income, better job opportunities without clear plan which results in temporary shelter in riverbanks, beside railways, and under bridges developing urban slums (Mojares, 2013). Usually, slum areas are prone to flooding during typhoon season. This poses challenges to Local Government Units (LGU) as they need to find and provide resources to sustain basic services for the residents.

According to the same study, there is also no improvement in the crime rate of the region. This can be linked to poverty - with less resources to provide basic services for the population results in petty crimes for them to put food on the table.

Environment degradation is evident in the region. Due to urban development, large and wild animals are confined in remote forests and mountains even with 24 protected areas. Rivers in Laguna Province pose risks for the population according to World Bank. This is due to industries located near the rivers. Areas near Laguna Lake are prone to flooding during typhoons (Mojares, 2013). 


\subsection{Sustainable Livelihood Framework as tool for Resiliency}

The concept of resilience has been studied by scholars from different fields. Holistically, the concept means the way of a system to plan, resist, and recover in stress and change (Bodland and Granberg, 2018). Community resiliency, as defined by Norris, et.al (2008), is "a process of linking a set of adaptive capacities to a positive trajectory of functioning and adaptation after a disturbance." Generally, the term focuses on the presence of disturbance and recovery of a community from disaster. According to Koliou, et.al (2018), there are three concepts that need to be focused on while studying community resilience; (a) consolidation and generalization of all available frameworks about resiliency, (b) correlation of social and economic aspect in the study of resiliency, and (c) development of "riskinformed decision-making tools"

In the study of Chandra, et.al (2010) entitled 'State of the research in community resilience; progress and challenges', there are five components in the study of resiliency physical and psychological wellbeing of the population, address issues in social and economic resources of the community, usage of tools and infrastructures to enhance preparedness and recovery, involvement of policy makers and government, and engagement of social networks.

With this, the study infer that there are three main key components in the study of resilience; (a) the shock or trends of hazard, (b) community networks or the capacities of community to recover from impact of hazard, and (c) innovation through policies and programs of the government to mitigate the negative effects of hazard. These three components are present in SLF. The framework is popularly used in assessing livelihoods in communities and the tool is also effective in evaluating community resilience. To justify this, Sustainable Livelihood Approach was used to evaluate the community resilience of Sudan from the study of Osman-Elasha, et.al (2005). SLF can be used as the framework can provide a holistic approach on how an intervention affects the life and livelihood of a community using various data collection methods. Furthermore, the five livelihood assets could present the adaptive capacity of a community and captures the changes in the livelihood assets of the community. In the study, the community identifies on the indicators and components of livelihood assets to measure resilience. 
Furthermore, as stated by Saxena, et.al (2016), SLF allows an understanding of community assets, policies and institutions that govern the community and their strategies. The framework provides quantitative and qualitative picture on the analysis of shocks that affect local communities, their network or capital, and process that influence a system.

Figure 1

\section{Sustainable Livelihood Framework}

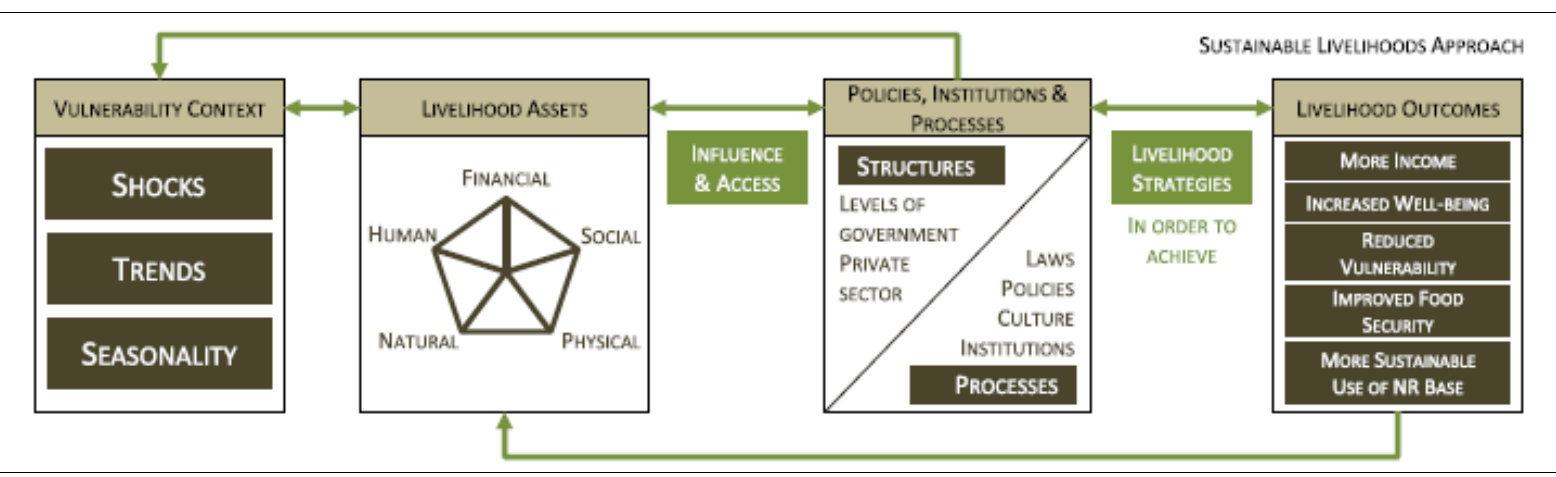

Source: Department for International Development (n.d.)

\subsection{Theoretical framework}

The study employs modified sustainable livelihood framework in the assessment of community resilience of Barangay Sala and Barangay Casile, Cabuyao City Laguna. As described in the literature, there are three factors in considering community resilience. They are (1) vulnerability context, (2) networks or capabilities, and (3) innovation. These factors are translated and categorized into the components of SLF.

Figure 2

\section{Modified Sustainable Livelihood Framework}

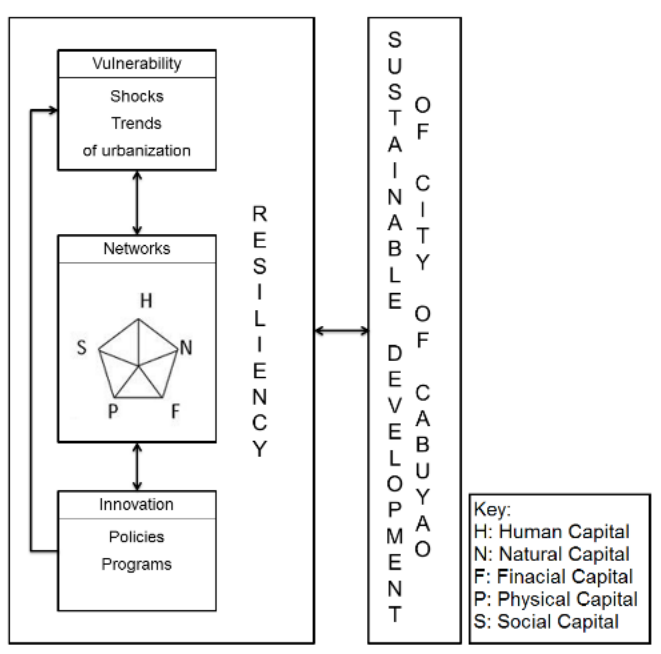


The vulnerability context in the framework are the shocks and trends brought by urbanization. It is the external and uncontrolled happenings in the society which affects the assets of the system. The community assets are the capacities and resource of the area that are affected by the trends and shocks of urbanization. These are categorized into five namely human, finance, social, physical, and natural. In this study, the indicators of these five assets are established based on secondary data (Table 1). The innovations are the policies and programs of the community that will improve community assets and mitigate the negative effects of urbanization. As the community becomes more resilient, sustainable development is more attainable.

Table 1

Indicators of Community Assets

\begin{tabular}{|c|c|c|}
\hline ASSETS & \multicolumn{2}{|c|}{ INDICATORS } \\
\hline Physical & $\begin{array}{l}\text { Number of House } \\
\text { Number of Building } \\
\text { Electrical Line } \\
\text { Water Line }\end{array}$ & $\begin{array}{c}\text { Communication Line } \\
\text { Roads } \\
\text { Vehicles }\end{array}$ \\
\hline Natural & $\begin{array}{c}\text { Water Quality } \\
\text { Soil Quality } \\
\text { Air Quality } \\
\text { Number of Waste or Garbage } \\
\text { Presence of Solid Waste Management }\end{array}$ & $\begin{array}{c}\text { Agricultural Lands } \\
\text { Terrestrial } \\
\text { Frequency of Disaster } \\
\text { Presence of Disaster Risk Reduction } \\
\text { Management }\end{array}$ \\
\hline Financial & $\begin{array}{r}\text { Number of fin } \\
\text { Povert } \\
\text { Br } \\
\text { Liy }\end{array}$ & $\begin{array}{l}\text { managements } \\
\text { idence } \\
\text { A } \\
\text { od }\end{array}$ \\
\hline Human & $\begin{array}{c}\text { Population } \\
\text { Working Age Population } \\
\text { Status of Health }\end{array}$ & $\begin{array}{l}\text { Unemployment } \\
\text { Educational attainment }\end{array}$ \\
\hline Social & $\begin{array}{c}\text { Education services } \\
\text { Health services } \\
\text { Presence of People's Organization }\end{array}$ & $\begin{array}{c}\text { Connectedness } \\
\text { Traffic } \\
\text { Presence of crime }\end{array}$ \\
\hline
\end{tabular}

\section{Methodology}

A key informant interview (KII) was conducted with the City Mayor to understand the shocks and trends of urbanization happening in the City. Focus Group Discussion (FGD) 
is employed with the officials of Barangay Sala, classified as Category 1 urban barangay and Barangay Casile, considered as Category 2 urban Barangay of Cabuyao City, Laguna ensuring quorum was attained. Before the data gathering process, an informed consent was established laying the steps that will take place during the FGDs and KII. Furthermore, anonymity of individuals participating in the research is ensured taking into account the confidentiality.

For the analysis of community assets, the officials were asked to rate the indicators with the use of semantic differential scale. The scale was developed and introduced by US psychologist Charles E. Osgood to capture the perception, affective and cognitive competencies of the respondents' connotation to certain concepts. For indicators measured in qualitative terms, a scale of 1 to 10 was used; 1 being low quality and 10 being high quality. While indicators measured in quantity, a scale of 0 to 10 was used with 0 being none and 10 being many. The 10 point scale was used for it capture the changes happening better and provide a higher degree of measurement. Furthermore, it has wide variance compared to the 5-point or 7-point scale.

Descriptive analysis was employed to interpret the changes of community assets and understand the perceived resilience of the two barangays. Same data analysis method was used in the analysis of the innovations of the leaders of barangays.

\section{Findings and Discussion}

\subsection{Vulnerability Context of Cabuyao City, Laguna}

As per the City Mayor, one of the trends of urbanization is the increase in the community budget. Cabuyao City was tagged as Richest Municipality in 2014, however this was not a good indicator of development. The nearby areas of the community which are Sta Rosa City, Calamba City, and Binan City converted as cityhood outperforming Cabuyao even with a budget of Php 600 - 700 million during 2010. Being one of the richest municipalities has negative implications especially in the internal revenue allotment (IRA) of the community. As a municipality, the community income will be divided into the total number of municipalities $(1,488)$ in the Philippines. In 2010, Cabuyao as the richest municipality, contributed higher income, however due to the huge number of municipalities, the community received a lower budget in return. After the implementation of its cityhood, the 
community budget increases as their income along with the income of other component and highly urbanized cities was divided into 140 cities in the Philippines.

Furthermore, another effect of urbanization is the transition of the community from municipal category and the implementation of cityhood last 2012. As a component city, the local government code mandated to have additional departments in the city office. This resulted to additional manpower and social services for its constituents. The institutionalization of the city has brought independence in terms of political decision making. For example, in terms of tax amnesty and tax incentive, municipalities in the Philippines need the approval of Provincial Government before granting to the investors. Meanwhile, in a city, the officials have the liberty to approve and permit tax amnesty and incentives which can bring more private companies in the area. The city government also partnered with the private sector to provide social services in the community. The city, for example, tapped industries in health sector to supply cheaper price of medicine and other hospital equipment to the public pharmacy and hospitals. Besides the increase of community income, the private companies provide jobs to the public.

Urbanization was also accompanied by influx of population due to migrants. Because of numerous job opportunities available in the area, rural people try their luck in the City. With the increase of working age population, this adds to the income in the city. However, this posed challenges as the number of jobs were not enough to cater the unemployed population as some may not be qualified due to low educational attainment which resulted in a high unemployment rate. Furthermore, the increase in population means an increase in provision of basic services. AS per the City Mayor, the city has no sufficient number of hospitals and schools to cater the 330,000 population. With no available hospitals, sick constituents are referred to nearby public hospital outside Cabuyao or nearest provincial hospital. To mitigate this, the government officials have approved the building of another government-run hospital with 300 bed capacities.

Traffic congestion becomes a problem as population increases. Curative approach is used by the city government to mitigate this problem such as road widening and strict parking implementation. In addition, environmental problems are evident in the community 
from the water pollution of Laguna lake to air pollution due to vehicles and industries. Land conversion can also be seen with the building of residential lands.

\subsection{Perception on Community Assets}

\subsubsection{Barangay Casile}

Barangay Casile, a Category 2 Urban Barangay, felt the process of urbanization in the community around 2010 due to the construction of road, electricity, and water supplies. The changes in physical asset were brought by the increase of houses (3-7), increase of buildings (1-3), increase of electrical lines (1-7.5), water lines (0-8.5), communication lines (5-8), roads (4-9), and vehicles (1-9). However, there were still areas of the community that did not have electrical lines. The respondents noted that there was a specific time frame where they can access water. The respondents said that the reason behind it is the increase of demand of water since resort businesses are present in the area. Furthermore, the mode of transportation in the community is tricycle though before there were jeepneys available in the area. The reasons of the removal of jeepneys were not specified. However, the respondents noted that there was an increase of private vehicles. Some of these problems are the result of the barangay's status as an upland location.

The residents had easier way of life due to the improvement in the road systems, water lines and electrical lines. The changes in the physical asset also brought economic progress in terms of household income. However, the respondents noted that because of the increase in houses brought by the increase of population, the community was distracted by noise pollution. Furthermore, there was also an increase of minor crimes in the barangay.

Barangay Casile has improved their natural assets. There was no change in the water quality (8-8) of the barangay because, as noted by the respondents, the water before 2010 was from the natural flowing water bodies such as river which is now being treated with chlorine. Both are high quality and safe to drink as perceived by the participants. There was a 1-point decline in the soil quality of the community. But, as agreed by the respondents, their

soil is still productive and fertile. Same as the water quality, the air quality (9-9) of the barangay had no change because the industries and factories were not located in their 
community. There was an increase in the community's waste (5-7) but the community could manage it through their solid waste management (4-8). The respondents said that their waste management before was having a compost or burning but nowadays, the LGU collects the garbage, and the community still has a compost. The community also experienced loss of agricultural lands; however, the community is still planting other crops, as stated by the respondents. The number of trees (7-9) increased because the community's committee of environment is active in tree planting activity. There was no account of change in the occurrence of disaster (5-5). The respondents determined that the barangay was prone to different hazards such as typhoons, landslides, and earthquakes. The DRRM (1-7) became better because the barangay was one of the focus of the LGU for Casile is located in the fault line.

The changes in the natural asset had affected the community positively and negatively. The residents had easier way of life because of the conversion of land to road systems and water lines. Before, the community imported a drum of water from nearby communities with a high price. There was also an increase of self-employed residents with sari-sari stores, and root crops farming such as rice. Furthermore, people's awareness regarding DRRM and Solid Waste Management has improved.

The disadvantage of the changes is the increase of price of fertilizers and feeds in the market. These inputs are important to the farmers. Due to this and the conversion of agricultural lands, some of the farmers venture to other sources of income such as sari-sari stores or by becoming employees.

All of the indicators for the financial asset improved. The barangay's financial establishments had minimal change with the community only having Smart Padala as a money transaction establishment. If the residents of the barangay wish to send money to other provinces, the residents must go to the City proper. The poverty incidence decreased from 7 to 5 . The barangay IRA increased from 3 to 9 and livelihood from 4 to 9 . The respondents noted that their barangay IRA was higher than the Poblacions'.

The changes in financial asset of the barangay resulted to the decrease of residents experiencing hunger. Furthermore, the honorarium of the officer increased which somewhat 
supported the officials economically. The improvement of barangay budget increased the community services and programs. The increase of resorts both affected the barangay in a positive and negative way. The increase of resort provided livelihood and increase the budget of barangay however, it caused the problem on water supply. The changes in financial asset resulted in an increase in the price of goods. The livelihood projects were problematic because there are no sure markets for the products.

In terms of human asset, the community's population and the working age increased from 2 to 6 . The health status (2-6) and educational attainment (3-8) of the residents improved because of the presence of barangay doctor, nurses and schools. Furthermore, unemployment decreased by 4 points.

The increase of population increased the budget of the barangay. There was also an increase in the scholarship grants in the barangay which resulted to increase of graduates. With the improvement on the educational attainment, the residents had better career. There were also negative effects such as security problems caused by migrants and strangers in the community.

On the other hand, the barangay's educational services and health services improved from 3 to 8 . The number of people's organization (3-8) and connection of the barangay to other organizations (3-8) also improved. The respondents identified some of the POs such as samahan ng mga magsasaka and samahan ng mga kababaihan. The community still do not experience traffic (0-0) however, there was an increase of minor crimes (3-6). The respondents noted that the usual suspects of crime are dayo/migrants.

The changes on social asset increased the literacy rate and there are more knowledgeable residents. These changes were brought by the improvement of education service in the community. As stated above, the increase of minor crimes caused by migrants and people outside the community was the negative impact. Table 2 summarizes the effects of urbanization to the community assets in Barangay Casile. 
Table 2

Effects of urbanization and innovations of Barangay Casile, Cabuyao City, Laguna.

TYPES OF ASSET

Before 2009

2017
EFFECTS OF CHANGES IN ASSETS Advantages

\section{Physical Asset}

- $\quad$ Easier way of life

- Economic progress
Disadvantages

- noise pollution

- increase of minor crimes and incidents

\begin{tabular}{c|c|c|}
\hline 1 & Electrical Line & 7.5 \\
\hline 0 & Water Line & 8.5 \\
\hline 5 & Communication Line & 8 \\
\hline 4 & Roads & 9 \\
\hline 1 & Vehicles & 9 \\
\hline
\end{tabular}

\section{Natural Asset}

\begin{tabular}{c|c|c|c|l|l}
\hline 8 & Water Quality & 8 & $\bullet$ & $\begin{array}{l}\text { Easier way of life } \\
\text { increase of self-employed } \\
\text { residents } \\
\text { increase in people's } \\
\text { awareness regarding SWM } \\
\text { and DRRM }\end{array}$ & $\begin{array}{l}\text { increase of price of } \\
\text { fertilizer and feeds in } \\
\text { the market }\end{array}$ \\
\hline 9 & Soil Quality & 7 & 9 & & \\
\hline 5 & Air Quality & No. of Waste & 7 & & \\
\hline 9 & $\begin{array}{c}\text { Solid Waste } \\
\text { Management }\end{array}$ & 8 & & & \\
\hline 7 & Agricultural Lands & 5 & & \\
\hline 5 & Terrestrial & 9 & & \\
\hline 1 & Disaster & 5 & & \\
\hline & $\begin{array}{c}\text { Disaster Risk } \\
\text { Reduction and }\end{array}$ & 7 & & \\
\hline
\end{tabular}

\begin{tabular}{|c|c|c|c|c|}
\hline \multicolumn{5}{|c|}{ Financial Asset } \\
\hline 0 & $\begin{array}{c}\text { Financial } \\
\text { Establishment }\end{array}$ & 1 & \multirow{4}{*}{$\begin{array}{l}\text { decrease of residents } \\
\text { experiencing hunger } \\
\text { increase of community } \\
\text { services and programs } \\
\text { - } \quad \text { increase of official's } \\
\text { honorarium } \\
\text { - increase of number of resorts }\end{array}$} & \multirow{4}{*}{$\begin{array}{l}\text { - } \quad \text { increase of price of goods } \\
\text { All items have a price } \\
\text { nowadays } \\
\text { increase of number of } \\
\text { resorts } \\
\text { - } \begin{array}{l}\text { no market for the product } \\
\text { of livelihood programs }\end{array}\end{array}$} \\
\hline 7 & Poverty incidence & 5 & & \\
\hline 3 & Brgy. IRA & 9 & & \\
\hline 4 & Livelihood & 9 & & \\
\hline \multicolumn{5}{|c|}{ Human Asset } \\
\hline 2 & Population & 6 & \multirow{5}{*}{$\begin{array}{l}\text { - Increase of barangay } \\
\text { budget } \\
\text { - } \quad \text { increase of scholarship } \\
\text { - } \quad \text { good working career }\end{array}$} & \multirow{5}{*}{ - migrants cause trouble } \\
\hline 2 & $\begin{array}{l}\text { Working Age } \\
\text { Population }\end{array}$ & 6 & & \\
\hline 2 & Health Status & 6 & & \\
\hline 6 & Unemployment & 2 & & \\
\hline 3 & $\begin{array}{l}\text { Educational } \\
\text { Attainment }\end{array}$ & 8 & & \\
\hline \multicolumn{5}{|c|}{ Social Asset } \\
\hline 3 & Education Services & 8 & \multirow{6}{*}{$\begin{array}{l}\text { - } \quad \text { increase in literacy rate } \\
\text { - knowledgeable community } \\
\text { members }\end{array}$} & \multirow{6}{*}{$\begin{array}{l}\text { Security problems due to } \\
\text { migrants }\end{array}$} \\
\hline 3 & Health Services & 8 & & \\
\hline 3 & $\begin{array}{c}\text { People's } \\
\text { Organizations }\end{array}$ & 8 & & \\
\hline 3 & Connectedness & 8 & & \\
\hline 0 & Traffic & 0 & & \\
\hline 3 & Crime & 6 & & \\
\hline
\end{tabular}


As a result of these changes in indicators, all the assets of Barangay Casile improved. The physical asset improved from 2.14 to 7.43 while the natural asset improved from 6.22 to 6.78. The betterment of financial (2.50-6.00), human (2.60-6.80) and social (4.83-7.68) asset can be seen (Figure 3).

\section{Figure 3}

Changes in community assets of Barangay Casile due to urbanization

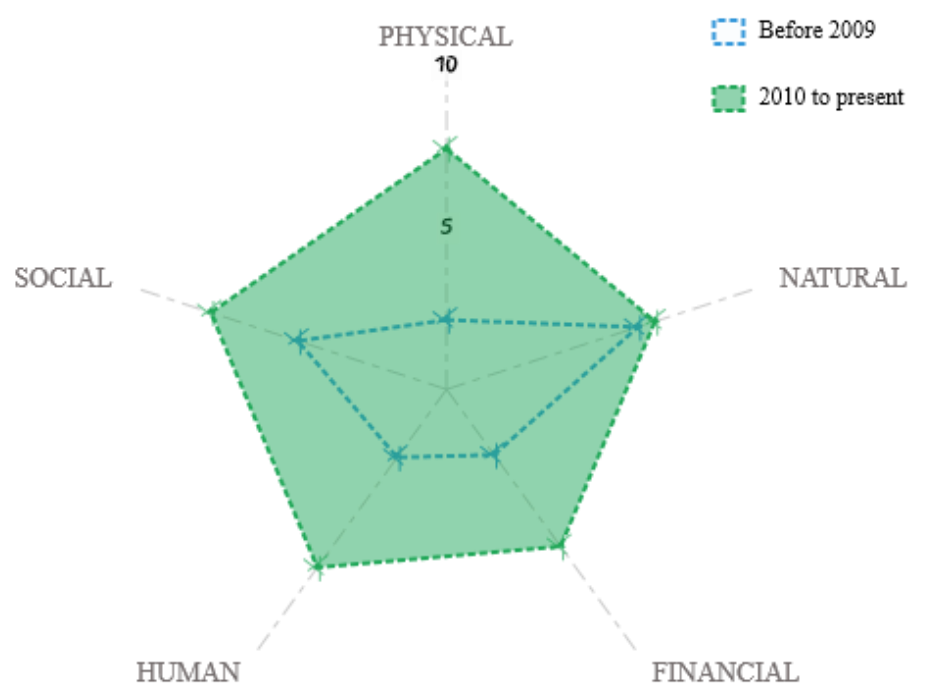

\subsubsection{Barangay Sala}

Sala, a Category 1 Urban Barangay, started to felt the development around the mid1980s when the change of government happened and the construction of industries and factories in the area had boomed. The number of houses (4-8) in Sala doubled because of the construction of subdivisions in the community, the number of buildings drastically increased from 1 to 10 because of the presence of factories and industries (Nestle and Tanduay are among the factories located in Barangay Sala). The water lines increased from 3 to 10 as well as the communication lines from 1 to 10 . The road systems also increased from 5 to 10 , but some roads are not in good quality. The number of vehicles also increased from 2 to 9 . There was no change in the electrical lines of the community (10-10). 
These changes in physical asset made the life of the residents' easier and made services accessible to them. The improvement of physical asset providing social services such as water lines, communication lines and electrical lines increased the expenses of the residents because of the additional payment. The increase of vehicles resulted in traffic, while the increase of houses which led to increase of population, water shortages and increase of waste.

For the natural asset, the water (10-5), soil (10-3) and air (10-3) quality worsened. As said by one of the respondents, the water is drinkable, however it is treated with chemicals. The barangay was known for producing high-quality garlic back when its soil was fertile. The number of waste drastically increased from 1 to 10 but because of this, the solid waste management improved from 4 to 8 . The LGU was the one managing the waste of the community through garbage collection. There was also a drastic decrease in the agricultural lands (10-2) and number of trees (10-5) in the barangay. The remaining agricultural lands in the area were privately owned. There was also an increase in the occurrence of disasters from 5 to 10 . The DRRM of the barangay improved significantly from 1 to 10 because of the presence of tanod/community police as a rescue team.

The changes in natural asset resulted to positive and negative impacts in the community. The low quality of water gave rise to the science of treating it, making it safer to drink. There was also an improvement in the knowledge of the residents regarding DRRM and hence low disaster-related mortality.

One of the negative impacts was the decrease of natural resources: one of the respondents stated that there were a lot of Maya, a type of bird in the community until the bird population started to decrease. The deterioration of natural resources made it impossible for future generations to see it. The decrease of agricultural land led to a decrease in food supply.

On the other hand, the financial establishments drastically increased from 0 to 8 as well as the barangay IRA. Some of the money transaction establishments identified were Metrobank, Laurel and Western Union. The livelihood of the barangay also improved from 2 to 9. Driving tricycles and jeepneys, having sari-sari stores, making rags and processed food 
were the identified livelihood present in the area. However, the poverty incidence has seen an increase from 3 to 7.

The changes in financial assets increased the quality of life of the residents in terms of income and increase of employment rate. Also, more jobs became available due to the increase of livelihood. However, there was an increase in minor crimes and robbery. The most recent robbery happened last November 30, 2009 in one of the banks in the community. One of the disadvantages was the absence of bankers' association.

For the human asset, the population as well as the working age population almost tripled (3-9). The health status of the residents worsened from 5 to 3. It was noted by one of the respondents that the life expectancy in the community decreased to 75 years unlike before that some of the residents could live up to 100 years. The unemployment rate was still the same (4-4).

The increase of population, as stated above, increased the barangay budget of the community. However, competition for services happened, especially in education, where school facilities are not enough to handle the growing population. Furthermore, it increased the number of minor crimes in the community.

In terms of social aspect, education and health services improved from 3 to 8 because free school supplies were being provided by the barangay. There was also an increase in the number of people's organizations from 3 to 7 with fraternities, women's organization, teacher's organizations, homeowners' association, and senior citizen organizations as the identified POs in the barangay. The connection of the barangay to other organizations also improved from 2 to 10. It is noted that the barangays in Cabuyao City coordinate with each other, unlike before. However, there was a drastic change in the presence of traffic (0-9) and crime (2-7).

The changes in social assets improved the participation of the community members especially the POs. The residents of the barangay were competitive in terms of education because they were literate. However, some of them seemed to be more knowledgeable on how to run the barangay than the barangay officials. Table 3 shows the type of assets, effects of urbanization and policies to mitigate the negative effects of the process. 
Table 2

Effects of urbanization and innovations of Barangay Sala, Cabuyao City, Laguna

TYPES OF ASSET

Before 1980s

2017

Advantages

Physical Asset

- Accessible services

- $\quad$ Easier way of life

\begin{tabular}{|c|c|c|}
\hline 4 & Number of House & 8 \\
\hline 1 & Number of Buildings & 7 \\
\hline 10 & Electrical Line & 10 \\
\hline 1 & Water Line & 10 \\
\hline 5 & Communication Line & 10 \\
\hline 2 & Roads & 8 \\
\hline
\end{tabular}

\begin{tabular}{|c|c|c|c|c|}
\hline \multicolumn{5}{|c|}{ Natural Asset } \\
\hline 10 & Water Quality & 5 & \multirow{8}{*}{$\begin{array}{ll}\text { - } & \text { Presence of water } \\
\text { treatment } \\
\text { - } & \text { DRRM awareness } \\
\text { - } & \text { Lower disaster-related } \\
& \text { mortality rate }\end{array}$} & \multirow{8}{*}{$\begin{array}{l}\text { - } \\
\text { - } \quad \text { Future generations cannot see } \\
\text { the natural resources } \\
\text { - } \quad \text { Decrease in food supply }\end{array}$} \\
\hline 10 & Soil Quality & 3 & & \\
\hline 10 & Air Quality & 3 & & \\
\hline 1 & No. of Waste & 10 & & \\
\hline 4 & $\begin{array}{l}\text { Solid Waste } \\
\text { Management }\end{array}$ & 8 & & \\
\hline 10 & Agricultural Lands & 2 & & \\
\hline 10 & Terrestrial & 5 & & \\
\hline 5 & Disaster & 8 & & \\
\hline 1 & $\begin{array}{l}\text { Disaster Risk } \\
\text { Reduction and } \\
\text { Management }\end{array}$ & 10 & & \\
\hline \multicolumn{5}{|c|}{ Financial Asset } \\
\hline 1 & $\begin{array}{l}\text { Disaster Risk } \\
\text { Reduction and } \\
\text { Management }\end{array}$ & 10 & \multirow{5}{*}{$\begin{array}{ll}\text { - } & \text { Increase in economic } \\
\text { development } \\
\text { - } & \text { Increased quality of life } \\
\text { - } & \text { Increase in employment } \\
\text { - } & \text { More } \\
\text { - } & \text { More jobs }\end{array}$} & \multirow{5}{*}{$\begin{array}{l}\text { Increase in minor crimes } \\
\text { including robbery } \\
\text { - No bankers' association }\end{array}$} \\
\hline 0 & $\begin{array}{c}\text { Financial } \\
\text { Establishment }\end{array}$ & 8 & & \\
\hline 3 & Poverty incidence & 7 & & \\
\hline 0 & Brgy. IRA & 8 & & \\
\hline 2 & Livelihood & 9 & & \\
\hline \multicolumn{5}{|c|}{ Human Assets } \\
\hline 3 & Population & 9 & \multirow{5}{*}{ - Increase in IRA } & \multirow{5}{*}{$\begin{array}{l}\text { - Competition in availing } \\
\text { community services } \\
\text { - Increase in minor crimes }\end{array}$} \\
\hline 3 & $\begin{array}{l}\text { Working Age } \\
\text { Population }\end{array}$ & 9 & & \\
\hline 5 & Health Status & 3 & & \\
\hline 4 & Unemployment & 4 & & \\
\hline & $\begin{array}{l}\text { Educational } \\
\text { Attainment }\end{array}$ & & & \\
\hline
\end{tabular}

\begin{tabular}{|c|c|c|c|c|}
\hline \multicolumn{5}{|c|}{ Social Asset } \\
\hline 3 & Education Services & 8 & \multirow{6}{*}{$\begin{array}{l}\text { - High participation of } \\
\text { community members } \\
\text { - Increase in competitiveness }\end{array}$} & \multirow{6}{*}{$\begin{array}{l}\text { - Community members seem } \\
\text { to be more knowledgeable } \\
\text { than the officials }\end{array}$} \\
\hline 3 & Health Services & 8 & & \\
\hline 3 & People's Organizations & 7 & & \\
\hline 2 & Connectedness & 8 & & \\
\hline 0 & Traffic & 9 & & \\
\hline 2 & Crime & 7 & & \\
\hline
\end{tabular}

- Increase in expenses

- Traffic

- $\quad$ Problem in Water supply

- Increase in wastes
Disadvantages

pply


While in the process of urbanization, Barangay Sala had seen to have improvement in their physical (3.71-8.86), financial (2.25-7.00), human (4.25-6.75), and social (4.83-6.00) asset. The natural asset, however, worsened from 7.67 to 4.33 giving negative impacts to the barangay (Figure 4).

Figure 4

Changes in community assets of Barangay Sala due to urbanization.

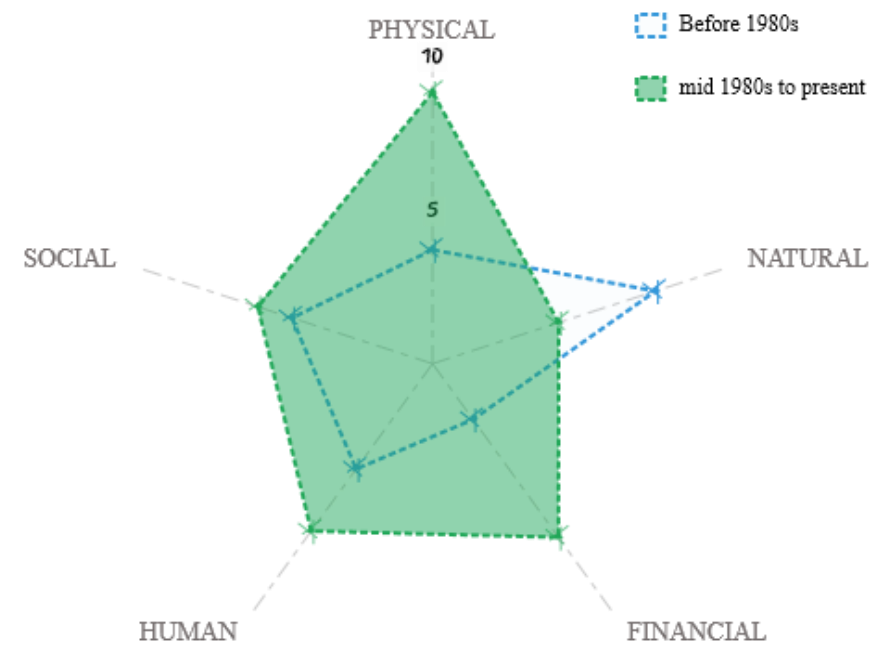

\subsection{Community Innovations}

\subsubsection{Barangay Casile}

To solve the problem of the increase of crimes and incidents, the barangay implemented curfew, anti-drug campaign, oplan sita and barangay census. Furthermore, the barangay has numerous programs such as Oplan Kalinisan (Tapat mo, Linis mo), Aso mo, Itali mo, No littering beside the streets, No cutting of trees, Tree planting, Training and seminars during disaster, and No construction of building at danger zone to further improve its natural assets. The barangay also partnered with factories for free seedlings to solve the increase of farming inputs (Table 4).

The barangay is strict in implementing its tax ordinance because of numerous resorts. This change also led to an increase of noise pollution which is eased by the videoke ordinance of the barangay (Table 4). 
As seen in Table 4, the improvement of the educational attainment of the community members was due to scholarship grants of the barangay and ALS. In health status and services, the barangay has a barangay doctor and implemented feeding and medical missions. The increase of minor crimes caused by migrants is answered by listing of migrants' profiles, UBAS, and drug campaigns.

Table 4

\section{Community Innovations of Barangay Casile.}

\begin{tabular}{|c|c|}
\hline Asset & Innovation (Community Policies, Programs and Projects) \\
\hline Physical & $\begin{array}{ll}\text { - } & \text { Curfew } \\
\text { - } & \text { Anti-Drugs campaign } \\
\text { - } & \text { Oplan Sita } \\
\text { - } & \text { Opmo, Itali mo Kalinisan } \\
\text { - } & \text { Brgy. census } \\
\text { - } & \text { Waste management policies }\end{array}$ \\
\hline Natural & $\begin{array}{l}\text { - } \quad \text { Training and seminars regarding disaster } \\
\text { - } \\
\text { - } \\
\text { - }\end{array}$ \\
\hline Financial & $\begin{array}{ll}\text { - } & \text { Tax ordinance } \\
\text { - } & \text { Videoke Ordinance }\end{array}$ \\
\hline Human & $\begin{array}{l}\text { - Scholarship program } \\
\text { - } \quad \text { Presence of barangay doctors }\end{array}$ \\
\hline Social & $\begin{array}{l}\text { - Listing of migrants's name } \\
\text { - Alternative Learning System } \\
\text { - Ugnayan ng Barangay at Simbahan } \\
\text { - } \quad \text { Feeding and medical miission } \\
\text { - } \quad \text { Drugs campaign }\end{array}$ \\
\hline
\end{tabular}

\subsubsection{Barangay Sala}

As seen in Table 5, officials of Barangay Sala have implemented policies and programs to mitigate the negative impacts of changes in physical asset such as parking ordinance to solve problems caused by traffic. Furthermore, the officials also proposed the 
construction of tents for the marketing of livelihood products by so-called Barangay Entrepreneurs. The increase of waste was alleviate by canal cleaning.

Table 5

Community Innovation of Barangay Sala

\begin{tabular}{|c|c|}
\hline Asset & Innovation (Community Policies, Programs and Projects) \\
\hline Physical & $\begin{array}{l}\text { - Planning or Barangay Enterpreneur } \\
\text { - Ongoing Parking ordinance } \\
\text { - Canal Cleaning }\end{array}$ \\
\hline Natural & $\begin{array}{l}\text { - } \quad \text { Participation of barangay in DRRM } \\
\text { - } \text { Agricultural programs (seeds and fertilizer) } \\
\text { - } \quad \text { Strict in converting agricultural lands to other land use } \\
\text { - } \quad \text { Waste segregation }\end{array}$ \\
\hline Financial & $\begin{array}{l}\text { - } 24 \text { hour patrolling } \\
\text { - } \quad \text { Free school supplies } \\
\text { - } \quad \text { Free medicines } \\
\text { - } \quad \text { Competitive barangay fees }\end{array}$ \\
\hline Human & $\begin{array}{ll}\text { - } & \text { Census } \\
\text { - } & \text { Job fair } \\
\text { - } & \text { Free medicines }\end{array}$ \\
\hline Social & $\begin{array}{ll}\text { - } & \text { Free education } \\
\text { - } & \text { Free school supplies } \\
\text { - } & \text { Curfew } \\
\text { - } & \text { Liquor ban } \\
\text { - } & \text { Videoke ordinance } \\
\text { - } & \text { No smoking }\end{array}$ \\
\hline
\end{tabular}

The negative change in natural assets also helped barangay officials and residents to participate in the activities of LGU. Further, the barangay has agricultural programs which provide seeds and fertilizers to the farmers and promote agriculture in the area. The barangay is also strict in the conversion of agricultural land to other uses.

The problems in minor crimes and robbery were mitigated by 24 hours patrolling of the barangay tanod. To further invite investors in the community, the barangay has lower fees for the private sector in order to provide more jobs for the residents. In addition, the barangay conducts job fairs regularly. 
To deliver medical and educational needs of the residents, the barangay provided free medicines and school supplies. Furthermore, the barangay has smoking policies in public places. In order to improve the security of the community; curfew, liquor ban and videoke ordinance were implemented.

\section{Conclusion}

The study showed the linkages of the three variables of the modified sustainable livelihood framework: vulnerability context, community assets and innovation. The trends and shocks of urbanization observed in Cabuyao City are increase in community budget, transition of municipal category to city which resulted to institutionalization, and influx of population due to migrants. The trends brought by urbanization was felt diversely by Barangay Casile and Barangay Sala as seen in the changes in their community assets. This was due to the difference in time when they felt the process of urbanization and the over-all impact of the trends in their community. Due to the differences in the impact on community assets, the two barangays have various program to improve these assets and mitigate the adverse effects in their community. Barangay Casile and Barangay Sala are still in the process to be resilient to mitigate the negative effects brought by urbanization and improve their ability and strength as a community.

\section{References}

Bodland, T., \& Granberg, M. (2018). The community resilience challenge - a case study from Sweden. Reframing Urban Resilience Implementation.

Chandra, A., Acosta, J., Meredith, L., Sanches, K., Stern, S., Uscher-Pines, L., Yeung, D. (2010). Understanding CommunityResilience in the Context of National Health Security. RAND Health.

Chaolin, G. (2019). Urbanization: positive and negative effects. Science Bulletin, 281-283.

Chaolin, G., Kesteloot, C., \& Cook, I. (2015). Theorising Chinese Urbanization: A Multilayered Perspective. Urban Studies.

Dahiya, B. (2014). Southeast Asia and sustainable urbanization. The Indonesian Journal of Leadership, Policy and World Affairs.

Department for International Development. (n.d.). Sustainable Livelihoods Guidance Sheet.

Dociu, M., \& Dunarintu, A. (2012). The Socio-Economic Impact of Urbanization . International Journal of Academic Research in Accounting, Finance and Management Sciences, 47-52. 
Ernston, H., van der Leeuw, S. E., Redman, C. L., Meffert, D. J., Davis, G., Alfsen, C., \& Elmqvist, T. (2010). Urban Transitions: On Urban Resilience and Human-Dominated Ecosystem. Royal Swedish Academy of Sciences.

Koliou, M., van de Lindt, J. W., McAllister, T. P., Ellingwood, B. R., Dillard, M., \& Cutler, H. (2018). State of the research in community resilience:. Sustainable and Resilient Infrastructure.

Ling Ooi, G., \& Hong Phua, K. (2007). Urbanization and Slum Formation. Journal of Urban Health.

Mojares, J. G. (2013). Urbanization and Its Effetcs in the CALABARZON Area, Philippines. Journal of Global Intelligence \& Policy, 24-40.

National Economic and Development Authority. (2017). Overlay of Economic Growth, Demographic Trends and Physical Characteristics. National Economic and Development Authority.

National Statistics Office. (2010). 2010 Census of Population and Housing.

Norris, F. H., Stevens, S. P., Pfefferbaum, B., Wyche, K. F., \& Pfefferbaum, R. (2008). Community Resilience as a Metaphor, Theory, Set of Capacities,. Am J Community Psychol, 127-150.

Osman-Elasha, B., Goutbi Elhassan, N., Ahmed, H., \& Zakieldin, S. (2005). Sustainable livelihood approach for assessing community resilience to climate change: case studies from Sudan. Assessments of Impacts and Adaptarions of Climare Change.

Philippine Statistics Authority. (2019, March 21). Philippine Statistics Authority. Retrieved from Urban Population in the Philippines (Results of the 2015 Census of Population): https://psa.gov.ph/content/urban-population-philippines-results-2015-censuspopulation

Sanyaolu, P., \& Sanyaolu, C. (2018, December 9). Urbanization. Nigeria.

Saxena, A., Guneralp, B., Bailis, R., Yohe, G., \& Oliver Chadwick. (2016). Evaluating the resilience of forest dependent communities in Central India by combining the sustainable livelihoods framework and the cross scale resilience analysis. Climate Change Impacts and Adaptation. 